\title{
MODERN IDEAS ABOUT ECOGENESIS
}

\author{
(C) Vladimir M. Evstropov, Ekaterina A. Trushkova \\ Don State Technical University, Rostov-on-Don, Russian Federation \\ v.evstr@mail.ru, rudenko-centr@mail.ru
}

\begin{abstract}
A.V. Kozachek proposed to call the process, characterizing the historical development of the content of ecological science and pedagogy, ecological genesis. In this regard, he proposed an approach according to which, in order to understand the essence and current state of the object of the professional activity of an environmental engineer, it is necessary to analyze the features of the development of environmental science in terms of the formation of a set of environmental knowledge as a tool of "transfer" in the learning process from a teacher to the listener in its development during historical time. From our point of view, ecogenesis can be considered much broader than just the evolution of the object of ecological knowledge and ecological knowledge. If we proceed from the fact that etymologically ecogenesis can be regarded as the origin of ecology, then its study should reflect the widely represented historical-ecological composition of its various aspects of theoretical and applied nature. Analyzed, developed by various researchers, methodological approaches, one way or another reflecting various aspects of ecology. Approaches to the study of ecological genesis are possible from the standpoint of classifications for the construction of ecological laws and theories, the periodization of ecology based on a change in paradigms, based on an analysis of the development of theoretical research in ecology, the study of ecology from the standpoint of a systemic and formalized mathematical approach. We believe that the whole set of analyzed approaches can serve as the basis for the doctrine of ecological genesis, reflecting the most diverse aspects of the emergence and development of ecology as a science and environmental education for the successful practical activity of a specialist in the field of ecology.

Key words: ecology, ecogenesis, periodization of ecology, conceptual systems, classification of the construction of ecological laws.
\end{abstract}

\section{[B.М. Евстропов, Е.А. Трушкова Современные представления об экологенезе]}

А.В. Козачек предложил процесс, характеризующий историческим развитием содержания экологической науки и педагогики, называть экологенезом. В этой связи им был предложен подход, согласно которому для понимания сущности и современного состояния объекта профессиональной деятельности инженера-эколога необходимо осуществлять анализ особенностей развития экологической науки в аспекте формирования совокупности экологических знаний как инструмента «передачи» в процессе обучения от преподавателя к слушателю в его развитии в течение исторического времени. С нашей точки зрения, экологенез можно рассматривать гораздо шире, чем только эволюцию объекта экологических знаний и экологического познания. Если исходить из того, что этимологически экологенез можно рассматривать как происхождение экологии, то его изучение должно отражать широко представленную историкоэкологическую композицию различных его аспектов теоретического и прикладного характера. Проанализированы, разработанные различными исследователями, методологические подходы, так или иначе отражающих различные аспекты экологенеза. Подходы к изучению экологенеза возможны с позиций классификаций построения экологических законов и теорий, периодизации экологии на основе смены в ней парадигм, на основе анализа развития теоретических исследований в экологии, изучения экологии с позиций системного и формализованно-математического подхода. Полагаем, что вся совокупность анализируемых подходов может служить основой учения об экологенезе, отражающем самые различные аспекты возникновения и развития экологии как науки и экологического образования для успешной практической деятельности специалиста в области экологии.

Ключевые слова: экология, экологенез, периодизация экологии, концептуальные системы, классификации построения экологических законов.

Vladimir M. Evstropov - M.D., Associate Professor, Don State Technical University, Rostov-on-Don, Russian Federation.

Ekaterina A. Trushkova - Ph.D. in Technical Sciences, Associate Professor, Don State Technical University, Rostov-on-Don, Russian Federation. 
Евстропов Владимир Михайлович - доктор медицинских наук, доцент, Донской государственный технический университет, г. Ростов-на-Дону, Российская Федерация.

Трушкова Екатерина Алексеевна - кандидат технических наук, доцент, Донской государственный технический университет, г. Ростов-на-Дону, Российская Федерация.

A.V. Kozachek proposed an approach according to which, in order to understand the essence and current state of the object of the professional activity of an environmental engineer, it is necessary to analyze the features of the development of environmental science, in the aspect of the formation of a set of environmental knowledge as a tool of "transfer" in the learning process from teacher to listener in its development during the historical time. The researcher called this process ecogenesis, which characterizes the historical development of the content of ecological science and pedagogy [13].

In this aspect, the objects of ecology are considered from the perspective of the professional activity of an ecologist. In particular, the aquatic environment is positioned as a water resource system [33], the regional space of interaction between the environment and human economic activity as a regional ecological and economic system [11]. As an object of activity of an environmental engineer, a natural-industrial system is considered, which has such properties as openness, uncertainty, complexity, etc., or a complex, but amenable to numerical description, eco-social-technical system [16].

From the point of view of ecology, as the development of the content of ecological science and pedagogy, the pre-ecological epoch is distinguished, characterized by initial attempts to systematize knowledge about the world around us, in particular, by the creation of various classifications of plants, animals, i.e. systems of species of living things that are in constant interconnection in a single biological system. At the same time, the study of natural biotic and abiotic factors affecting organisms (zoogeography, biogeography) and the creation of theories of natural resources began.

For the first ecological epoch of the development of ecological science and pedagogy, it is characteristic that the object of study was taken to be individual organisms experiencing the influence of various natural factors in the environment and forced to adapt to their action using morphological, physiological and ontological mechanisms. This was considered from the standpoint of the synthesis of biological sections of natural science and economic sections of social science. The second epoch of ecogenesis is the study of unified supraorganism systems, represented by a set of organisms, united by connections and relationships and competing with each other for existence in conditions of a limited amount of resources. The content of the third era of ecogenesis was the formation of ecology as an independent science.

In the fourth era of ecogenesis, biological systems were considered as systems experiencing human influence through other biological systems artificially modified by him or manmade systems artificially created by him, the existence and development of which both depends not only on the availability and inflow of resources from outside, but also on the will human. The fifth epoch of ecogenesis is characterized by the penetration of man beyond the terrestrial biosphere into the technosphere expanded to near-Earth cosmic limits, which includes, in addition to the human-populated biosphere of the Earth, the shells of life at interplanetary stations, spacecraft (arte-biosphere) [4] The coming sixth epoch of ecogenesis is characterized by a new stage of development of the object of ecological knowledge, the stage of exartisphere, i.e. technogenic environmental impacts that differ from abiotic and biotic environmental factors [13].

In the fourth era of ecogenesis, biological systems were considered as systems experiencing human influence through other biological systems artificially modified by him or manmade systems artificially created by him, the existence and development of which both de- 
pends not only on the availability and inflow of resources from outside, but also on the will human. The fifth epoch of ecogenesis is characterized by the penetration of man beyond the terrestrial biosphere into the technosphere expanded to near-Earth cosmic limits, which includes, in addition to the human-populated biosphere of the Earth, the shells of life at interplanetary stations, spacecraft (arte-biosphere) [4] The coming sixth epoch of ecogenesis is characterized by a new stage of development of the object of ecological knowledge, the stage of exartisphere, i.e. technogenic environmental impacts that differ from abiotic and biotic environmental factors [13].

It should be noted that greening is considered the most important requirement of modernity. One of the main forms of the greening trend is the development of sciences that are transitional from ecology to other sciences of the biological cycle, to earth sciences, to sciences of the physical and chemical cycle, to technical and agricultural sciences. At the same time, according to L.G. Bodnar and co-authors, environmental education is the task of the humanities, in particular, philological sciences [3].

From our point of view, the consideration of ecogenesis, only as an evolution of the object of ecological knowledge, somewhat narrows the very idea of analyzing ecogenesis. If we proceed from the fact that etymologically ecogenesis can be regarded as the origin of ecology (genesis - from the Greek. Genesis: the origin of something), then its study should reflect the widely presented historical and ecological composition of its various aspects of theoretical and applied character. In this regard, it seems appropriate to briefly analyze other methodological approaches to the periodization of ecology, its theoretical studies and conceptual systems, developed by various researchers.

Let's consider the approach of V.A. Kobylyansky on the interpenetration of philosophical and ecological knowledge, which is the methodological basis of private ecological disciplines: geoecology, bioecology, socioecology, anthropoecology and their numerous modifications, including at the global, regional, local level. This author believes that the "ecosystem" is the initial concept of the general theory of ecology in the general scientific sense, as a complex system that represents the unity and interaction of any central object (geosystem, biosystem, sociosystem, anthro-posystem) and the ecosystem. The ecological interaction of the central object and the ecological environment itself determines the qualitative nature of the ecosystem as a whole. The typology of this interaction is the general basis for the classification of ecological knowledge and the basis for the corresponding typology of ecosystems [12].

M.D. Goldfein et al. also believes that ecological interaction serves as the main category of general ecology, being essentially the interaction of some "central" object with a set of other objects (elements, systems, conditions, etc.), i.e. the environment. According to these researchers, the understanding of such an ecological paradigm is directly related to the interpretation of ecology in the broadest sense (general ecology) [7].

If we consider ecology from the standpoint of interpreting ecology in a broad sense (general ecology), in our opinion, it is necessary to dwell on general methodological approaches to the construction of environmental laws and theories. Currently, several classifications of the construction of environmental laws and theories are known. For example, in accordance with one of them, three main approaches are distinguished, each of which can initiate the emergence of a relatively closed system of knowledge and give an adequate description of the factual data: causal (cause-effect relationships), historical (temporal relationships) and finalist (based on functional characteristics). According to another classification, the physicochemical, historical and systemic aspects of life are distinguished, which are necessary for the construction of theoretical structures of science [1, 30]. The historical approach appears in both classifications, therefore, it plays an important role in the study of the construction of environmental laws and theories. Based on this, we present some analytical approaches to the study of environmental laws and theories in the historical aspect. 
G.S. Rosenberg et al. developed a periodization of ecology, taking as a basis the change of paradigms in it [23-27]. According to this periodization, researchers consider the first period of ecology to be preparatory from ancient times to 1866, when the concept of "ecology" was defined by Ernst Haeckel and justified as an independent scientific discipline. The peculiarities of this period are in the appearance of elements of ecology "in the works of botanists, zoologists and other naturalists in the absence of a conceptual apparatus of its own for ecology. The development of ecology from the standpoint of the concept of "ecosystem" is characteristic of the second period (1866-1935). In this period, first of all, factorial ecology was formed and regularities in the attitude of animals or plants to various abiotic factors (autecological reductionism) were revealed [5]. The third period (from 1936 to the beginning of the 1970s) is considered by researchers as a period of synecological research, priority in relation to the study of the relationships of populations in ecosystems, the methodology of which was based on the use of the systemic approach in its deterministic version - the development of mathematical ecology and a variety of analytical as well as simulation models of ecosystems. As a result, the research basis of this period was formed by the following provisions:

- design of ecology as a fundamental theoretical discipline,

- the idea of the predominant finding of nature in equilibrium,

- synecological approach,

- primacy of competitive relations,

- small "share" of evolutionary factors in the development of ecosystems,

- the formation of an idea of the discreteness of ecosystems, manifested by the desire to classify evolutionary factors;

- dominance of deterministic (strictly functional) ideas about the interconnections of components in ecosystems.

For studies and researchers of the fourth period of development of ecology, which lasted from the early 1970s to the mid-1980s, the following regularities were characteristic:

- difficulties in identifying some general laws of community development,

- constant violations of equilibrium states,

- renewed interest in population research,

- rejection of competition as the main factor in the formation of a community,

- study of ecosystems in their development,

- dominance of the concept of continuum over the concept of discreteness of ecosystems,

- the increasing role of random factors in explaining the structure and dynamics of ecosystems [34].

And finally, the fifth period, covering the last 30-40 years, characterized by a tendency to unite the concepts of the deterministic-population second period, the deterministicsynecological third and stochastic-population fourth periods, which characterizes the beginning of the formation of a truly systemic approach to the study of environmental objects. This approach is most successfully presented by M. Bigon [2].

B.M. Mirkin and L.G. Naumov added another period of prehistory of ecology in the $18^{\text {th }}$. $19^{\text {th }}$ centuries, when three main approaches were laid, which were developed in the 20th century: autecological (K. Linnaeus, J. B. Lamarck, A. Gum-boldt, K. F. Rulier, C.R. Darwin, E. Haeckel); population (T.R. Malthus, C.R. Darwin) and ecosystem-biosphere (K. Linnaeus, A.L. Lavoisier, J. B. Lamarck, A. Humboldt, E. Haeckel, V.V.Dokuchaev) [18].

When analyzing the development of theoretical research in ecology, G.S. Rosenberg comes to the conclusion that ecology as a scientific discipline is characterized by three stages of development: descriptive, conceptual-theoretical and the stage of mathematization of these concepts (formal-theoretical) [24]. The author believes that the descriptive period of 
ecology as a scientific discipline is generally relatively complete, the conceptual-theoretical period is in its prime, but the formal-theoretical period is in the process of its formation.

O.V. Malyukova analyzes the conceptual systems of ecology in a chronological aspect. From the standpoint of the first conceptual system of ecology, the vital activity of populations and the functioning of biogeocenoses unfold within the framework of clearly specified spatiotemporal indicators, going beyond which is characterized as temporary and transient. In this case, the ideal image of the population and biocenosis is interpreted in the form of oscillatory changes, and ecology is defined as "the unity of the biotope and biocenosis". The basic concept of homeostasis is introduced, on the basis of which the ecology of populations, the ecology of communities, the functioning of ecosystems, the functioning of the biosphere, the ecology of man and mankind are considered.

The second conceptual system of ecology is social ecology - a scientific direction that began to take shape in the second half of the twentieth century. In practical terms, its result was the creation of a new technical discipline - engineering, or industrial, ecology - and a new direction of activity engineering protection of the environment.

The third conceptual system of ecology is associated with a gradual transition to the study of a new reality - the process of globalization. Ecosystem studies are obvious steps towards global ecology, since global ecology is the totality of all ecosystems [31]. Engineering ecology is considered as the fourth conceptual system of ecology [17, 20].

One of the significant achievements of ecology in recent decades should be considered the increased attention to the development of the methodology of science - a systematic approach based on seven principles of rational thinking $[9,14,15]$ : the principle of consistency (the possibility of studying an object as a system); expediency (definition of the research goal); emergence (the presence of systemic properties that require research); structural and functional organization (explanation of the interaction of elements and the formation of emergent functions); hierarchy (determining the number of levels when studying the system); integrity (the dependence of parts on the whole); historicism (the history of the formation of the object) [10].

In the 1960s, the integrative direction in the study of communities and ecosystems has intensified due to the wide penetration of the ideas of cybernetics and information theory into ecology. An important role in this was played by the works of R. Margalef, in which the systemic and self-organizing nature of communities was emphasized, and the concept of information was widely used to describe them [6].

Initially, the first mathematical models used in ecology were models based on standard statistical methods, including different types of distribution functions of certain characteristics (factors). Much later, already in the 20th century, multiple regression and multivariate analysis of variance appeared in models.

Since the beginning of the 19th century, differential equations have been used in models in ecology. Relatively recently, the game approach [22] and the group-theoretical approach to the study of the interaction of environmental factors, using the symmetry of the population survival function [8], have been attributed to the number of approaches used in mathematical models in ecology. Since the beginning of 2000. When assessing the quality of natural ecosystems, as well as the anthropogenic load on lotic ecosystems, the Harrington desirability function was used. One of the relatively new methods used in ecology is also multifractal analysis based on the phenomenon of self-similarity [21].

Thus, in addition to the approach to the study of ecogenesis, which is characterized by the historical development of the content of ecological science and pedagogy, in our opinion, there are many other approaches that somehow reflect various aspects of ecogenesis. These are, first of all, approaches to environmental education [3, 28]. Z.I. Tyumasev and I.L. Orekhova believe that in the process of human cognition of ecology, a logical chain is built: first 
from the network of relationships between man and nature to human ecology, then to a special type of this ecology, which is expediently called pedagogical ecology, since it is not addressed so much. to directly to relationships, but above all to their formation in a person. In this regard, according to the authors, in science such concepts as "environmental pedagogy", "environmental education" or simply "education" are established, if it is meant to be natural [29].

Approaches to the study of ecogenesis from the standpoint of classifications of the construction of ecological laws and theories are also known $[1,30]$, the periodization of ecology based on the change of paradigms in it [23-27.], Based on the analysis of the development of theoretical research in ecology [24], ecology from the standpoint of a systemic and formalized-mathematical approach [8, 21, 22]. We believe that the entire set of the analyzed approaches can serve as the basis for the doctrine of ecogenesis, reflecting the most diverse aspects of the emergence and development of ecology as a science and ecological education for the successful practical activity of a specialist in the field of ecology. One can think that ecology as a branch of knowledge evolves as the knowledge of ecosystems from the simplest physical and ecological concept to the globalization of ecology in the form of an interdisciplinary field of knowledge about the structure and functioning of multi-level systems in nature and society in their interconnection [32].

\section{Лumepamypa}

1. Бауэр Э.С. Теоретическая биология. СПб.: Росток, 2002. 352 с.

2. Бигон М., Харпер Дж., Таунсен д К. Экология. Особи, популяции, сообщества. В 2-х т. М.: Мир, 1989, т. 1. 667 с.

3. Боднар Л.Г., Воронина В.Э., Сдобнова С.О. История развития экологии как науки и экологизация наук - необходимый этап развития общества // Аспирант и соискатель. 2011. № 6. С.11-13.

4. Вассоевич Н.Б., Иванов А.Н. О биосфере и мегабиосфере // Журнал общей биологии. 1983. Т. 44. №3. С. 291-303.

5. Гиляров А.М. Методологические проблемы современной экологии. Смена ведущих концепций // Природа, 1981. №9. С. 96-103.

6. Гиляров А.М. Методологические проблемы современной экологии. Смена ведущих концепций // Русский орнитологический журнал. 2014. Т. 23. Экспресс-выпуск 1036: C. 2523-2535.

7. Гольдфрейн М.Д., Иванов А.В., Яшков И.А., Кочнев А.М. Экология: синтез естественнонаучного, технического и гуманитарного знания (по итогам серии всероссийских научно-практических конференций) // Вестник технологического университета. 2015. Т.18. № 16. С. 270-282.

8. Гуламов М.И. Теоретико-групповой подход к исследованию взаимодействия экологических фракторов // Экологическая химия. 2012. Т. 21. №1. С. 1-9.

9. Джефрферс Дж. Введение в системный анализ: применение в экологии. М.: Мир, 1981. 256 c.

10. Зорина А.А. Законы и закономерности теоретической экологии // Астраханский вестник экологического образования. 2019. Т. 50. № 2. С. 183-191.

11. Изард У. Методы регионального анализа: введение в науку о регионах / Пер. с англ. В.М. Хомана, Ю.Г. Липеца, С.Н. Тагера. М.: Прогресс, 1966. 660 с.

12. Кобылянский В.А. Глобализация и экология: новый подход к созданию основ общей теории экологии // Ученые записки Забайкальского государственного гуманитарно-педагогического университета им. Н.Г. Чернышевского. 2009. №4. С. 2533. 
13. Козачек A.В. Эволюция объекта экологических знаний в рамках экологенеза // Юг России: Экология. Развитие. 2016. Т.11. № 1. С.37-58.

14. Колесников Л.А. Основы теории системного подхода. Киев: Наук. Думка. 1988. $171 \mathrm{c}$.

15. Коросов А.В. Имитационное моделирование в среде MS Excel (на примерах из экологии). Петрозаводск: ПетрГУ, 2002. 212 с.

16. Мазур И.И., Молдаванов О.И. Курс инженерной экологии. М.: Высшая школа, 1999. $447 \mathrm{C.}$

17. Малюкова О.В. Концептуальные системы экологии и экологическая стрела времени // Вестник МГОУ. Серия Философские науки. 2011. № 2. С. 8-34.

18. Миркин Б. М., Наумова Л.Г. Краткий курс общей экологии. Часть І: Экология видов и популяций: Учебник. Уфра: Изд-во БГПУ, 2011. 206 с.

19. Немтинов B.A. Информационный анализ и моделирование объектов природнопромышленной системы. М.: Машиностроение-1. 2005. 112 с.

20. Николайкин Н.И., Николайкина Н.Е., Мелехова О.П. Экология: Учебное пособие. М.: МГУИЭ, 2000. 504 с.

21. Одинец В.П. Об истории некоторых математических моделей в экологии // Вестник Сыктывкарского университета. Серия 1: Математика. Механика. Инфрорматика. 2017. Т. 24. Выпуск 3. С.88-103.

22. Петросян Л.А., Захаров В.В. Введение в математическую экологию. Л.: Изд-во ЛГУ, 1986. 222 с.

23. Розенберг Г.С. О периодизации экологии // Экология. 1992. № 4. С. 3-19.

24. Розенберг Г.С. Конспект построения теоретической экологии // Известия Самарского научного центра Российской академии наук. 2003. Т. 5. № 2. С.189-206.

25. Розенберг Г.С., Мозговой Д.П. Узловые вопросы современной экологии: Учебное пособие. Самара: СамГУ, 1992. 120 с.

26. Розенберг Г.С., Мозговой Д.П., Гелашвили Д.Б. Экология. Элементы теоретических конструкций современной экологии (Учебное пособие). Самара: Самарский научный центр РАН, 2000. 396 с.

27. Розенберг Г.С., Рянский Ф.Н. Теоретическая и прикладная экология: Учебное пособие. Нижневартовск: Изд-во Нижневарт. пед. ин-та, 2005. 292 с.

28. Садыкова Э.Ф., Мирюгина Т.А. Гуманитарное развитие экологической науки // Проблемы современного педагогического образования. 2019. № 63-1. С. 282285.

29. Тюмасева 3.И., Орехова И.Л. Периодизация взаимоотношений человека с окружающей природной средой как фактор вариативности образования // Вестник Челябинского государственного педагогического университета. 2017. № 3. С. 95101.

30. Хлебосолов Е.И. Избранные статьи // Поведение, экология и эволюция животных: труды, статьи, монографии / Под общ. ред. В.М. Константинова. Т.1. Рязань: Голос губернии, 2009. С. 25-151.

31. Egerton F. N. History of Ecological Sciences, Part 63: Biosphere Ecology. The Bulletin of the Ecological Society of America. 2019. Vol. 100, Iss. 3. URL: https://esajournals.onlinelibrary.wiley.com/doi/epdf/10.1002/bes2.1568

32. Evstropov V.M., Trushkova E.A., Egorova Yu.N. General Characteristic of Modern Ecology Structure // Научный альманах стран Причерноморья. 2019. Том 18. №2. C. 48-57. URL: http://science-almanac.ru/documents/259/2019-02-07-Evstropov.pdf

33. Maas A. (ed.). Design of Water-Resource System. New Techniques for Relating Economic Objectives, Engineering Analysis and Governmental Planning. HarvardCambridge: Harvard University Press, Cambridge, Mass.1962, 620 p. 
34. Simberloff $D$. A succeassion of paradigms in ecology: Form essentialism and probabllism // Synthese. 1980, v. 43. P. 3-39.

\section{References}

1. Bauer E.S. Teoreticheskaya biologiya [Theoretical biology]. Saint Petersburg: Rostok, 2002. 352 p. (In Russian).

2. Bigon M., Kharper Dzh., Taunsen $d$ K. Ekologiya. Osobi, populyatsii, soobshchestva [Ecology. Individuals, populations, communities]. 2 Vol. Moscow: Mir, 1989, V.1. 667 p. (In Russian).

3. Bodnar L.G., Voronina V.E., Sdobnova S.O. Istoriya razvitiya ekologii kak nauki i ekologizatsiya nauk - neobkhodimyy etap razvitiya obshchestva [The history of the development of ecology as a science and the greening of sciences is a necessary stage in the development of society]. Aspirant i soiskatel. 2011. No. 6. pp.11-13 (In Russian).

4. Vassoyevich N.B., Ivanov A.N. O biosfere i megabiosfere [On the biosphere and megabyosphere]. Zhurnal obshchey biologii. 1983. V.44. No. 3. pp. 291-303 (In Russian).

5. Gilyarov A.M. Metodologicheskiye problemy sovremennoy ekologii. Smena vedushchikh kontseptsiy [Methodological problems of modern ecology. Change of leading concepts]. Priroda, 1981. No. 9. pp. 96-103 (In Russian).

6. Gilyarov A.M. Metodologicheskiye problemy sovremennoy ekologii. Smena vedushchikh kontseptsiy [Methodological problems of modern ecology. Change of leading concepts]. Russkiy ornitologicheskiy zhurnal. 2014. V. 23. Ekspress-vypusk 1036: pp. 2523-2535 (In Russian).

7. Goldfeyn M.D., Ivanov A.V., Yashkov I.A., Kochnev A.M. Ekologiya: sintez yestestvennonauchnogo, tekhnicheskogo i gumanitarnogo znaniya (po itogam serii vserossiyskikh nauchno-prakticheskikh konferentsiy) [Ecology: synthesis of natural science, technical and humanitarian knowledge (based on the results of a series of allRussian scientific and practical conferences)]. Vestnik tekhnologicheskogo universiteta. 2015. V.18. No. 16. pp. 270-282 (In Russian).

8. Gulamov M.I. Teoretiko-gruppovoy podkhod $k$ issledovaniyu vzaimodeystviya ekologicheskikh faktorov [Group-theoretical approach to the study of the interaction of environmental factors]. Ekologicheskaya khimiya. 2012. V.21. No. 1. pp. 1-9 (In Russian).

9. Dzheffers Dzh. Vvedeniye v sistemnyy analiz: primeneniye v ekologii [Introduction to Systems Analysis: Application in Ecology]. Moscow: Mir, 1981. 256 p. (In Russian).

10. Zorina A.A. Zakony i zakonomernosti teoreticheskoy ekologii [Laws and patterns of theoretical ecology]. Astrakhanskiy vestnik ekologicheskogo obrazovaniya. 2019. V. 50. No. 2. pp. 183-191 (In Russian).

11. Izard $U$. Metody regionalnogo analiza: vvedeniye $v$ nauku o regionakh [Methods of regional analysis: an introduction to the science of regions]. Moscow: Progress, 1966. 660 p. (In Russian).

12. Kobylyanskiy V.A. Globalizatsiya i ekologiya: novyy podkhod k sozdaniyu osnov obshchey teorii ekologii [Globalization and ecology: a new approach to the creation of the 
foundations of the general theory of ecology]. Uchenyye zapiski Zabaykalskogo gosudarstvennogo gumanitarno-pedagogicheskogo universiteta im. N.G. Chernyshevskogo. 2009. No. 4. pp. 25-33 (In Russian).

13. Kozachek A.V. Evolyutsiya obyekta ekologicheskikh znaniy $v$ ramkakh ekologeneza [Evolution of the object of ecological knowledge in the framework of ecogenesis]. Yug Rossii: Ekologiya. Razvitiye. 2016. V.11. No. 1. pp. 37-58 (In Russian).

14. Kolesnikov L.A. Osnovy teorii sistemnogo podkhoda [Foundations of the theory of the systems approach]. Kiyev: Nauk. Dumka. 1988. 171 p. (In Russian).

15. Korosov A.V. Imitatsionnoye modelirovaniye $v$ srede MS Excel (na primerakh iz ekologii) [Simulation modeling in MS Excel (on examples from ecology)]. Petrozavodsk: PetrGU, 2002. 212 p. (In Russian).

16. Mazur I.I., Moldavanov O.I. Kurs inzhenernoy ekologii [Environmental Engineering Course]. Moscow: Vysshaya shkola, 1999. 447 p. (In Russian).

17. Malyukova O.V. Kontseptualnyye sistemy ekologii i ekologicheskaya strela vre-meni [Conceptual systems of ecology and the ecological arrow of time]. Vestnik MGOU. Seriya Filosofskiye nauki. 2011. No. 2. pp. 8-34 (In Russian).

18. Mirkin B.M., Naumova L.G. Kratkiy kurs obshchey ekologii. Chast I: Ekologiya vidov i populyatsiy: Uchebnik [A short course in general ecology. Part I: Ecology of Species and Populations: Textbook]. Ufa: Izdatelstvo BGPU, 2011. 206 p. (In Russian).

19. Nemtinov V.A. Informatsionnyy analiz i modelirovaniye obyektov prirodnopromyshlennoy sistemy [Information analysis and modeling of objects of the natural and industrial system]. Moscow: Mashinostroyeniye-1. 2005. 112 p. (In Russian).

20. Nikolaykin N.I., Nikolaykina N.Ye., Melekhova O.P. Ekologiya: Uchebnoye posobiye [Ecology: Textbook]. Moscow: MGUIE, 2000. 504 p. (In Russian).

21. Odinets V.P. Ob istorii nekotorykh matematicheskikh modeley v ekologii [On the history of some mathematical models in ecology]. Vestnik Syktyvkarskogo universiteta. Seriya 1: Matematika. Mekhanika. Informatika. 2017. V. 24(3). pp. 88-103 (In Russian).

22. Petrosyan L.A., Zakharov V.V. Vvedeniye v matematicheskuyu ekologiyu [Introduction to Mathematical Ecology]. Leningrad: Izdatelstvo LGU, 1986. 222 p. (In Russian).

23. Rozenberg G.S. O periodizatsii ekologii [On the periodization of ecology]. Ekologiya. 1992. No. 4. pp. 3-19 (In Russian).

24. Rozenberg G.S. Konspekt postroyeniya teoreticheskoy ekologii [Abstract of the construction of theoretical ecology]. Izvestiya Samarskogo nauchnogo tsentra Rossiyskoy akademii nauk. 2003. V. 5. No. 2. pp.189-206 (In Russian).

25. Rozenberg G.S., Mozgovoy D.P. Uzlovyye voprosy sovremennoy ekologii: Uchebnoye posobiye [Key issues of modern ecology: Textbook]. Samara: SamGU, 1992. 120 p. (In Russian).

26. Rozenberg G.S., Mozgovoy D.P., Gelashvili D.B. Ekologiya. Elementy teoreticheskikh konstruktsiy sovremennoy ekologii (Uchebnoye posobiye) [Elements of theoretical constructions of modern ecology (textbook)]. Samara: Samarskiy nauchnyy tsentr RAN, 2000. 396 p. (In Russian). 
27. Rozenberg G.S., Ryanskiy F.N. Teoreticheskaya i prikladnaya ekologiya: Uchebnoye posobiye [Theoretical and Applied Ecology: Textbook]. Nizhnevartovsk: Izdatelstvo Nizhnevartovskogo pedagogicheskogo instituta, 2005. 292 p. (In Russian).

28. Sadykova E.F., Miryugina T.A. Gumanitarnoye razvitiye ekologicheskoy nauki [Humanitarian development of environmental science]. Problemy sovremennogo pedagogicheskogo obrazovaniya. 2019. No. 63-1. pp. 282-285 (In Russian).

29. Tyumaseva Z.I., Orekhova I.L. Periodizatsiya vzaimootnosheniy cheloveka s okruzhayushchey prirodnoy sredoy kak faktor variativnosti obrazovaniya [Periodization of human relations with the natural environment as a factor of variability in education]. Vestnik Chelyabinskogo gosudarstvennogo pedagogicheskogo universiteta. 2017. No. 3. pp. 95-101 (In Russian).

30. Khlebosolov Ye.l. Izbrannyye stati. Povedeniye, ekologiya i evolyutsiya zhivotnykh: trudy, stati, monografii [Selected articles. Behavior, ecology and evolution of animals: works, articles, monographs] V.1. Ryazan: Golos gubernii, 2009. pp. 25-151 (In Russian).

31. Egerton F.N. History of Ecological Sciences, Part 63: Biosphere Ecology. The Bulletin of the Ecological Society of America. 2019. Vol. 100, Iss. 3. Available at: https://esajournals.onlinelibrary.wiley.com/doi/epdf/10.1002/bes2.1568

32. Evstropov V.M., Trushkova E.A., Egorova Yu.N. General Characteristic of Modern Ecology Structure. Science Almanac of Black Sea Region Countries. 2019. V. 18. No. 2. pp. 48-57. Available at: http://science-almanac.ru/documents/259/2019-02-07Evstropov.pdf

33. Maas A. (ed.). Design of Water-Resource System. New Techniques for Relating Economic Objectives, Engineering Analysis and Governmental Planning. HarvardCambridge: Harvard University Press, Cambridge, Mass.1962, 620 p.

34. Simberloff $D$. A succession of paradigms in ecology: Form essentialism and probabllism. Synthese. 1980, V.43. pp. 3-39. 